\title{
Penggunaan Metode Eksperimen Untuk Meningkatkan Pemahaman Konsep Dan Keterampilan Proses Siswa Tentang Pengaruh Kegiatan Manusia Terhadap Keseimbangan Lingkungan Dalam Pembelajaran IPA Di Kelas VI SD Negeri 4 Imbanagara Raya Kecamatan Ciamis Kabupaten Ciamis
}

\author{
Sudrajat \\ SD Negeri 4 Imbanagara Raya Kecamatan Ciamis Kabupaten Ciamis Alamat dan Kota \\ Email : sudrajat_kepala@yahoo.co.id
}

\begin{abstract}
This Classroom Action Research is titled "Penggunaan Metode Eksperimen Untuk Meningkatkan Pemahaman Konsep Dan Keterampilan Proses Siswa Tentang Pengaruh Kegiatan Manusia Terhadap Keseimbangan Lingkungan Dalam Pembelajaran IPA Di Kelas VI SD Negeri 4 Imbanagara Raya Kecamatan Ciamis Kabupaten Ciamis". This research is conducted, because it is still widely found in the field, especially in schools where researchers are tasked that science learning is only carried out through the lecture method and assignment only. The mean score of students' understanding comprehension is 61.50 or below the minimal score. So even the science process skills in learning is not achieved maximally. As a solution to overcome these problems researchers use experimental methods or experiments in learning. Based on the above problems are formulated as follows: (1) how the level of understanding of student concepts about the effect of human activities on the environment after going through experimental methods ?; (2) what is the level of students' science process skill after application of experimental method? This research method is Classroom Action Research conducted three cycles. Indicators and subject matter in each cycle were developed and adapted to the science material of Class VI Primary School with KTSP 2006. The location of the research was conducted at SD Negeri 4 Imbanagara Raya District Ciamis Ciamis Regency. The subjects of the study were students of class VI of academic year 2016/2017 semester II, which totaled 24 students with details of 12 male students and 13 female students. The instruments used in this study are Experimental Journals, Observation, Test Results Learning Results, and Questionnaire. The results obtained is to use experimental methods to improve understanding of concepts and skills of the students process about the influence of human activities on environmental balance in science learning in class VI SD Negeri 4 Imbanagara Raya District Ciamis Ciamis Regency. The average value of student learning outcomes in the first cycle of meeting 1 of 68.13; cycle I meeting 2 is 72,29; the second cycle of meeting 1 is 80.21 ,
\end{abstract}


and the second cycle of meeting 2 is 85.83 . Similarly, the students' science process skills in each cycle are always improving, especially the observing aspect.

\section{Keyword: Experimental methods, process skills, environment.}

Abstract - PTK ini berjudul "Penggunaan Metode Eksperimen untuk Meningkatkan Pemahaman Konsep dan Keterampilan Proses Siswa Tentang Pengaruh Kegiatan Manusia Terhadap Keseimbangan Lingkungan dalam Pembelajaran IPA di Kelas VI SD Negeri 4 Imbanagara Raya Kecamatan Ciamis Kabupaten Ciamis". Penelitian ini dilakukan, karena masih banyak ditemukan di lapangan terutama di sekolah tempat peneliti bertugas bahwa pembelajaran IPA hanya dilaksanakan dengan melaui metode ceramah dan penugasan saja. Nilai rata-rata pemahaman konsep siswa sebesar 61,50 atau di bawah nilai KKM. Begitu pun keterampilan proses sains dalam pembelajaran tidak tercapai secara maksimal. Sebagai solusi untuk mengatasi permasalahan tersebut peneliti menggunakan metode eksperimen atau percobaan dalam pembelajaran. Berdasarkan hal tersebut dirumuskan masalah sebagai berikut: (1) bagaimana tingkat pemahaman konsep siswa tentang pengaruh kegiatan manusia terhadap lingkungan setelah melalui metode eksperimen?; (2) bagaimana tingkat keterampilan proses sains siswa setelah diterapkannya metode eksperimen? Metode penelitian ini adalah Penelitian Tindakan Kelas yang dilakukan tiga siklus. Indikator dan pokok bahasan pada setiap siklusnya dikembangkan dan disesuaikan dengan materi IPA kelas VI Sekolah Dasar dengan KTSP 2006. Lokasi penelitian dilakukan di SD Negeri 4 Imbanagara Raya Kecamatan Ciamis Kabupaten Ciamis. Subjek penelitian adalah siswa kelas VI tahun pelajaran 2016/2017 semester II, yang berjumlah seluruhnya 24 siswa dengan rincian 12 siswa laki-laki dan 13 siswa perempuan. Instrumen yang digunakan dalam penelitian ini adalah Jurnal Eksperimen, Observasi, Soal Tes Hasil Belajar, dan Angket. Adapun hasil yang diperoleh adalah dengan menggunakan metode eksperimen dapat meningkatkan pemahaman konsep dan keterampilan proses siswa tentang pengaruh kegiatan manusia terhadap keseimbangan lingkungan dalam pembelajaran IPA di kelas VI SD Negeri 4 Imbanagara Raya Kecamatan Ciamis Kabupaten Ciamis. Nilai rata-rata hasil belajar siswa pada siklus I pertemuan 1 sebesar 68,13; siklus I pertemuan 2 sebesar 72,29; siklus II pertemuan 1 sebesar 80,21, dan siklus II pertemuan 2 sebesar 85,83 . Demikian pula dengan keterampilan proses sains siswa setiap siklusnya selalu mengalami peningkatan terutama aspek mengamati.

\section{Kata Kunci : Metode eksperimen, keterampilan proses, lingkungan.}

\section{Pendahuluan}

Pendahuluan memuat identifikasi masalah, tinjauan pustaka, tujuan penelitian, serta manfaat yang didapatkan dari hasil penelitian.Paragraf dimulai menjorok ke dalam seperti dalam contoh paragraf ini. Huruf yang digunakan adalah Times New Roman, 10 pt, spasi tunggal, dengan paragraf yang diratakan kiri dan kanan (justified).

Pembelajaran Ilmu Pengetahuan Alam (IPA) berhungan dengan cara mencari tahu tentang alam secara sistematis, sehingga IPA bukanlah hanya penguasaan kumpulan pengalaman berupa fakta-fakta, konsep-konsep, atau prisip-prinsip saja tetapi juga merupakan proses penemuan. Oleh karena itu proses pembelajaran IPA 
di SD/MI menekankan pada pemberian pengalaman belajar secara langsung melalui penggunaan dan pengembangan keterampilan proses dan sikap ilmiah ( BNSP, 2006: 143).

Di dalam pembelajaran IPA siswa diharuskan mendapatkan banyak kesempatan untuk mengembangkan keterampilan dengan melakukan berbagai kegiatan yang berkaitan dengan materi pembelajaran IPA.

Dalam pembelajaran IPA yang harus dinilai adalah proses dan hasil yang bertujuan untuk memperoleh gambaran bagaimana siswa dapat melakukan sebuah proses dan bagaimana hasil yang ditempuh siswa selama mengikuti pembelajara IPA. Hal ini berhubungan dengan salah satu tujuan Mata Pelajaran IPA di SD/MI dalam KTSP, yaitu mengembangkan keterampilan proses untuk menyelidiki alam sekitar, memecahkan masalah dan membuat keputusan. Dalam mengembangkan keterampilan proses, kegiatan-kegiatan percobaan proses kejadian atau eksperimen perlu dilakukan, karena keterampilan proses sangat berhubungan dengan percobaan atau eksperimen. Bila eksperimen dilakukan di dalam IPA, maka keterampilan proses siswa akan terlihat dan dapat dinilai. Keterampilan proses yang harus dimiliki siswa di antaranya mengamati, mengukur, mengklasifikasi, mencari hubungan ruang/waktu, membuat hipotesis, merencanakan penelitian/eksperimen, mengendalikan menginterprestasi, variable, meramalkan, dan mengkomunikasikan (Semiawan, 1985: 17 ).

Sudah dikatakan di awal, bahwa salah satu alternatif model pembelajaran IPA yang diterapkan untuk meningkatkan keterampilan proses dan memberikan penguatan terhadap kualitas pembelajaran IPA di SD sebagai sarana penelitian adalah metode eksperimen. Metode ini sesuai untuk mengembangkan keterampilan motorik, kognitif, dan afektif bahkan meningkatkan sikap ilmiah siswa. Dengam menggunakan metode eksperimen akan mudah mengamati bagaimana cara siswa belajar, mengambangkan keterampilan dan bagaimana siswa menemukan sendiri fakta dan konsep. Pada usia Sekolah Dasar umumnya siswa berpikirnya masih secara nyata. Hal ini sesuai dengan pendapat Piaget dalam Winataputra ( 1992: 153 ), bahwa pada usia SD siswa masih berada pada tahap operasional konkret ( 7-11 tahun ), pada tahap ini anak mulai berpikir logis dan menerapkan pada masalahmasalah yang konkret atau nyata.Kegiatan pada tahap ini sangat berkaitan dengan pengalaman yang bersifat konkret dan belum berfikir formal. Anak pada usia tahap ini belum mampu menangani hal-hal yang abstrak seperti hipotesa atau proposisi verbal.

Akan tetapi pada kenyataannya, saat penulis melakukan observasi dan wawancara di sekolah yang menjadi tempat penelitian penulis, ternyata dalam proses pembelajaran IPA kebanyakan masih berpusat pada guru yang hanya melakukan informasi, ceramah, melihat buku teks yang dilanjutkan dengan pembahasan secara verbal tanpa adanya percobaan atau bentuk pembelajaran konkret lainnya.Sehingga keterampilan proses siswa masih kurang bahkan tidak nampak.

Penulis pun menemukan hasil prestasi siswa mata pelaran IPA di SD Negeri 4 Imbanagara Raya Kecamatan Ciamis Kabupaten Ciamis rendah terlihat dari 22 siswa di kelas VI hanya mendapat nilai rata-rata 61,50 atau di bawah KKM. Adapun nilai KKM di sekolah tersebut untuk mata pelajaran IPA yaitu 63. Hal ini, ternyata selain yang diutarakan di atas 
penyebanya yaitu cara guru dalam penyampaian materi pelajaran kurang menarik akibatnya siswa menjadi cepat merasa bosan dan kurang memperhatikan penjelasan guru. Ini dapat dikatakan bahwa kondisi buruk yang terjadi dalam kegiatan pembelajaran tersebut disebabkan kurang atau bahkan tidak nampaknya bentuk penggunaan metode yang tepat oleh guru.Dengan kata lain permasalahan tersebut mengidentifikasikan bahwa proses pembelajaran IPA di SD masih memerlukan inovasi dan pengembangan model atau metode pembelajaran yang dapat mengaktifkan siswa dalam kegiatan ilmiah dan memudahkan guru dalam pencapaian tujuan pembelajaran. Adapun metode yang penulis maksudkan adalah metode eksperimen.

Eksperimen atau percobaan merupakan komponen yang sangat penting dalam pembelajaran IPA di SD. Kegiatan eksperimen dapat menjawab pernyataan bahwa kegiatan pembelajaran pada anakanak usia Sekolah Dasar bersifat konkret. Teori Piaget mengidentifikasikan bahwa diperlukan proses penerjemahan dari materi abstrak menjadi lebih konkrit, sehingga materi yang abstrak tersebut dapat tersampaikan dan siswa akan lebih memahami dan dimunkinkan akan mudah dalam menguasai konsep-konsep IPA. Melalui kegiatan eksperimen, konsepkonsep IPA yang bersifat abstrak akan lebih tampak nyata dan kontekstual.

Berdasarkan uraian masalah di atas dan merujuk dari kelebihan metode eksperimen yang dipaparkan di atas, maka penulis merasa perlu dan terdorong untuk melakukan penelitian lebih lanjut dan mengangkatnya dalam sebuah skripsi dengan judul "Penggunaan Metode Eksperimen untuk Meningkatkan Pemahaman Konsep dan Keterampilan Proses Siswa Tentang Pengaruh Kegiatan Manusia Terhadap Keseimbangan
Lingkungan Dalam Pembelajaran IPA di Kelas VI SD Negeri 4 Imbanagara Raya Kecamatan Ciamis Kabupaten Ciamis".

Berdasarkan latar belakang masalah di atas maka permasalahan penelitian ini adalah, sebagai berikut.

1. Bagaimana tingkat pemahaman konsep siswa tentang pengaruh kegiatan manusia terhadap keseimbangan lingkungan setelah melalui metode eksperimen?

2. Bagaimana tingkat keterampilan proses sains siswa setelah diterapkan metode eksperimen?

Untuk menghindari kesimpangsiuran penelitian ini, maka perlu adanya tujuan yang hendak dicapai oleh peneliti. Sejalan dengan masalah yang peneliti kemukakan pada rumusan masalah. Maka tujuan yang hendak dicapai oleh peneliti dalam penelitian ini adalah :

1. mengetahui tingkat pemahaman konsep siswa mengenai pengaruh kegiatan manusia terhadap keseimbangan lingkungan setelah melalui metode eksperimen di kelas VI SD Negeri 4 Imbanagara Raya Kecamatan Ciamis Kabupaten Ciamis ; dan

2. mengetahui tingkat keterampilan proses sains siswa setelah diterapkan metode eksperimen di kelas VI SD Negeri 4 Imbanagara Raya Kecamatan Ciamis Kabupaten Ciamis. Dari hasil penelitian ini, penulis berharap dapat memberikan manfaat, baik secara teoritis maupun secara praktis. Secara teoritis hasil penelitian ini dapat dijadikan sebagai pedoman pemilihan metode pembelajaran Pengaruh Kegiatan Manusia Terhadap Lingkungan (ekosistem).

Secara praktis hasil penelitian ini diharapkan dapat memberikan sumbangan bagi :

1. Siswa 
- Dapat meningkatkan penguasan konsep dalam pembelajaran IPA khususnya pada pembelajaran Pengaruh Kegiatan Manusia Terhadap Keseimbangan Lingkungan.

- Dapat meningkatkan keterampilan proses siswa dalam melaksanakan pembelajaran IPA dengan menggunakan metode eksperimen.

- Dapat meningkatkan terjadinya interaksi, aktivitas, dan kerjasama antar siswa dalam pembelajaran Pengaruh Kegiatan Manusia Terhadap Keseimbangan

2. Guru

$$
\text { Lingkungan }
$$

- Dapat memberikan wawasan dan pengalaman dalam menyusun model pembelajaran IPA dengan metode eksperimen.

- Dapat memperoleh masukan dari hasil penelitian tindakan kelas sebagai pemecahan masalah dalam pembelajaran IPA di mana penulis bertugas.

- Dapat meningkatkan upaya guru dalam mata pelajaran IPA dengan metode eksperimen khususnya dalam pembelajaran Pengaruh Kegiatan Manusia Terhadap Keseimbangan Lingkungan.

- Dapat meningkatkan kinerja dan profesional guru dalam mengajar.

3. Lembaga ( Sekolah )

- Dapat dijadikan sebagai masukan dalam penyediaan dan pengolahan sumber belajar di sekolah.

- Dapat memberikan kontribusi untuk meningkatkan kualitas sekolah khususnya pada mata pelajaran IPA.

\section{METODE PENELITIAN}

Cara termudah untuk mengikuti aturan format halaman PETIK adalah menggunakan format dalam dokumen ini. Simpanlah file ini dengan nama lainnya, lalu ketikkan isi makalah anda ke dalamnya.

\section{A. Setting dan Subjek Penelitian}

Penelitian ini dilaksanakan di SD Negeri 4 Imbanagara Raya Kecamatan Ciamis Kabupaten Ciamis. Alasan penulis mengambil lokasi ini karena antara sekolah tempat penelitian dengan rumah tempat tinggal penulis cukup dekat, selain itu sekolah tersebut merupakan tempat penulis mengajar sehingga perijinan untuk melakukan penelitian pun tidak sulit didapat. Yang menjadi subjek penelitian adalah siswa kelas VI SD Negeri 4 Imbanagara Raya Kecamatan Ciamis tahun pelajaran 2016/2017 semester genap, dengan jumlah siswa sebanyak 24 siswa, terdiri dari 12 siswa laki-laki dan 12 siswa perempuan.

Adapun waktu pelaksanaan penelitian dilaksanakan pada semester II tahun pelajaran 2016/2017 adapun rincian pelaksanaan penelitian yaitu 2 siklus 4 pertemuan.

Pelaksanaan kegiatan dapat dilaksanakan sebagai berikut:

1. Persiapan penelitian 02 Februari 2017

2. Perijinan penelitian dari Kepala Sekolah 20 Februari 2017

3. Pelaksanaan penelitian sebagai berikut :

- Siklus I pertemuan 1 dilaksanakan hari Senin tanggal 06 Maret 2017,

- Siklus I pertemuan 2 dilaksanakan hari Senin tanggal 13 Maret 2017,

- Siklus II pertemuan 1 dilaksanakan hari Senin tanggal 20 Maret 2017, 
- Siklus II pertemuan 2 dilaksanakan hari Senin tanggal 27 Maret 2017.

4. Pengolahan hasil penelitian 03 April 2017

5. Seminar hasil penelitian hari Sabtu tanggal 22 April 2017

6. Pelaporan hasil penelitian 26 April 2017

\begin{tabular}{|c|c|c|}
\hline No & NiIai & Kriteria \\
\hline 1 & $<60$ & Rendah \\
\hline 2 & $61-75$ & Cukup \\
\hline 3 & $76-90$ & Tinggi \\
\hline 4 & $91-100$ & Tinggi Sekali \\
\hline
\end{tabular}

TABEL 2

KRITERIA KETUNTASAN BELAJAR SISWA

\section{B. Prosedur Penelitian}

Prosedur penelitian terdiri dari observasi awal, identifikasi masalah, dan perencanaan tindakan siklus I pertemuan 1, siklus I pertemuan 2, siklus II pertemuan 1, sampai siklus II pertemuan 2.

\section{Teknik Pengumpulan Data}

Teknik pengumpulan data terdiri dari lembar observasi, soal hasil evaluasi, dan angket.

\section{Teknik Analisis Data}

Dalam penelitian ini dilakukan teknik analisis data dengan cara menganalisis data yang diperoleh melalui jurnal/kegiatan eksperimen, observasi, tes, dan angket. Data yang diperoleh disusun dan dipilih menjadi data kemampuan awal dan kemampuan akhir (hasil belajar), aktivitas siswa (keterampilan proses). Menafsirkan data sesuai dengan teori, hasil penelitian, aturan normatif guru dan peneliti untuk memperoleh rujukan dalam melakukan tindakan selanjutnya. Hasil dari semua data diambil untuk dijadikan sebuah kesimpulan dalam keberhasilan pembelajaran yang telah dicapai.

\section{E. Indikator Kebehasilan}

Tolak ukur atau kriteria keberhasilan penelitian ini dapat dilihat dari dua sisi, yaitu dari sisi proses dan dari sisi hasil.

TABEL 1

KRITERIA PENILAIAN PENGUASAAN MATERI

\begin{tabular}{|c|c|c|}
\hline No & NiIai & Kriteria \\
\hline 1 & $0,00-1,00$ & Kurang \\
\hline 2 & $1,01-2,00$ & Sedang \\
\hline 3 & $2,01-3,00$ & Baik \\
\hline 4 & $3,01-4,00$ & Baik Sekali \\
\hline
\end{tabular}

\section{HASIL PENELITIAN DAN PEMBAHASAN}

Setelah menganalisis dan merefleksi data yang diperoleh pada siklus I pertemuan 1, siklus I pertemuan 2, siklus II pertemuan 1 , dan siklus II pertemuan 2 maka selanjutnya penulis membahas setiap data yang diperoleh sebagai berikut.

\section{A. Nilai dan Hasil Persentase Kelompok dalam mengerjakan Kegiatan Eksperimen/ Percobaan pada Siklus I Pertemuan 1, Siklus I Pertemuan 2, Siklus II Pertemuan 1, dan Siklus II Pertemuan 2}

Berdasarkan data hasil jurnal eksperimen yang dikerjakan oleh setiap kelompok pada setiap siklusnya berbeda. Pada siklus I pertemuan 1, rata-rata nilai jurnal eksperimen dari seluruh kelompok adalah 82,5 \% dengan skor tertinggi 100 dan skor terendah 60. Ini membuktikan bahwa kegiatan yang dilakukan setiap kelompok terhadap pemahaman yang mereka miliki menegenai materi pokok "Pengaruh kegiatan manusia (penggunaan detergen) terhadap keseimbangan ekosistem" dengan indikator "Menjelaskan akibat/ pengaruh penggunaan bahan kimia dan detergen pada lingkungan melalui pengamatan" 
Pada siklus I pertemuan 2 rata-rata nilai jurnal eksperimen dari seluruh kelompok mengalami peningkatan rata-rata 90 dengan skor tertinggi 100 dan skor terendah 70. Ini membuktikan bahwa pengetahuan yang dimiliki siswa dalam kelompoknya pada materi pokok "Pengaruh kegiatan manusia (penggunaan pestisida) terhadap keseimbangan ekosistem" dengan indikator "Menjelaskan akibat/ pengaruh penggunaan bahan pestisida pada lingkungan melalui pengamatan" dapat dikatakan cukup baik dan mengalami peningkatan dari siklus I pertemuan 1 .

Pada siklus II pertemuan 1 rata-rata nilai jurnal eksperimen dari seluruh kelompok mengalami peningkatan rata-rata 92,5 dengan skor tertinggi 100 dan skor terendah 90. Ini membuktikan bahwa pengetahuan yang dimiliki siswa dalam kelompoknya pada materi pokok "Pengaruh kegiatan manusia (penggunaan pestisida) terhadap keseimbangan ekosistem" dengan indikator "Menjelaskan akibat/ pengaruh penggunaan bahan pestisida pada lingkungan melalui pengamatan" dapat dikatakan cukup baik dan mengalami peningkatan dari siklus I pertemuan 2.

Begitu pula pada siklus II pertemuan 2 rata-rata nilai jurnal eksperimen dari seluruh kelompok mengalami peningkatan rata-rata 97,5 dengan skor tertinggi 100 dan skor terendah 90. Ini membuktikan bahwa pengetahuan yang dimiliki siswa dalam kelompoknya pada materi pokok "Pengaruh kegiatan manusia (penggunaan pupuk yang berlebihan) terhadap keseimbangan ekosistem" dengan indikator "Menjelaskan akibat/ pengaruh penggunaan pupuk secara berlebihan pada lingkungan melalui pengamatan" dapat dikatakan cukup baik dan mengalami peningkatan dibandingkan dengan siklus sebelumnya.

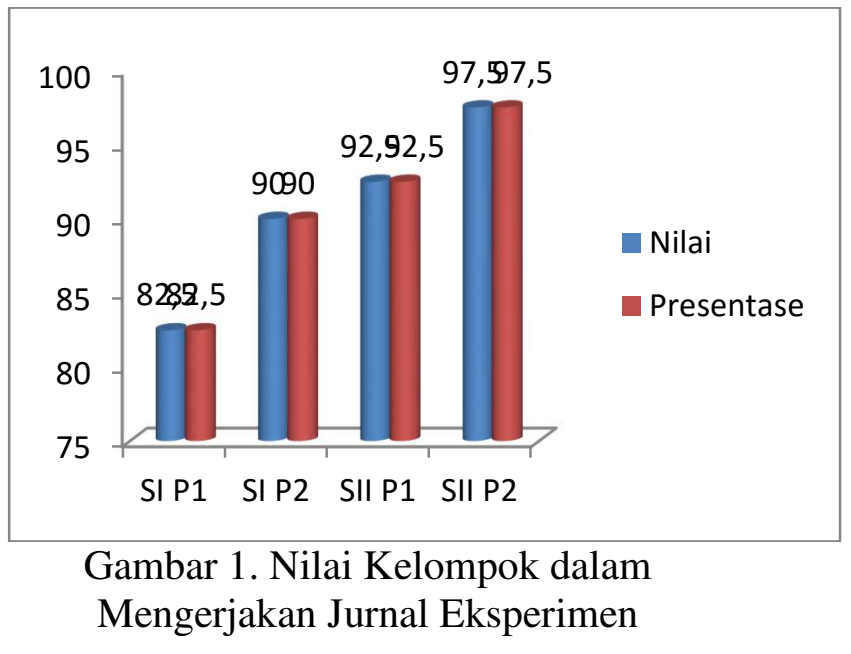

\section{B. Hasil Observasi Keterampilan Proses Kelompok pada Siklus Siklus I Pertemuan 1, Siklus I Pertemuan 2, Siklus II Pertemuan 1, dan Siklus II Pertemuan 2}

Judul makalah harus berukuran $24 \mathrm{pt}$, Times New Roman, rata tengah, seperti contoh.Nama penulis harus dalam ukuran 11 pt. Nama institusi penulis harus dalam ukuran 10 pt dan cetak miring (italic). Alamat email harus dalam ukuran $9 \mathrm{pt}$ dengan teks Courier.

Dari hasil observasi kelompok, pada siklus I pertemuan 1 keterampilan proses belum terlihat dengan baik, pada siklus I pertemuan 2 keterampilan proses yang dilakukan setiap kelompok mengalami peningkatan. Begitu pula pada siklus II pertemuan 2 hasilnya lebih baik dan lebih meningkat lagi.

Jika dilihat dari setiap kemampuan keterampilan proses Sains pada setiap siklus berbeda. Pada Siklus I pertemuan 1 rata-rata dari seluruh kelompok dalam keterampilan mengamati mencapai nilai 3 menunjukan kriteria baik, keterampilan interpretasi data 2,5 menunjukan kriteria baik, dan keterampilan berkomunikasi 2,5 menunjukan kriteria baik. Pada Siklus I pertemuan 2 rata-rata dari seluruh kelompok dalam keterampilan mengamati mencapai nilai 4 menunjukan kriteria baik, keterampilan interpretasi data 3,3 
menunjukan keterampilan kriteria baik, berkomunikasi

dan 3,3 menunjukan kriteria baik. Pada siklus II pertemuan 1 mengalami peningkatan, yaitu dalam keterampilan mengamati mencapai nilai 4 menunjukkan kriteria baik sekali, keterampilan interpretasi data 3,5 menunjukkan kriteria baik sekali, dan keterampilan berkomunikasi 3,5 menunjukkan kriteria baik sekali. Sedangkan pada siklus II pertemuan 2 lebih meningkat lagi, yaitu dalam keterampilan mengamati mencapai nilai 4 menunjukkan kriteria baik sekali, keterampilan interpretasi data 3,5 menunjukkan kriteria baik sekali, dan keterampilan berkomunikasi 4 menunjukkan kriteria baik sekali

Berdasarkan uraian di atas membuktikan bahwa keterampilan proses dalam setiap kelompok pada setiap siklusnya mengalami peningkatan. Keterampilan proses sains yang mengalami peningkatan lebih cepat adalah keterampilan proses mengamati (observasi). Hal ini terlihat dari antusias pada setiap kelompok dan hampir semua mata siswa dari setiap anggota kelompok fokus untuk melihat dan mengamati proses terjadinya pencemaran air akibat pengaruh kegiatan manusia (menggunakan bahan seperti detergen, pestisida, dan pupuk yang berlebihan) yang berakibat hewan air/ ikan menjadi mati.

Dalam kegiatan eksperimen setiap kelompok diharuskan melakukan praktek/ percobaan langsung serta harus dapat menyimpulkan sendiri dari hasil percobaannya. Setiap kelompok dilatih menggunakan alat peraga dengan baik dan benar. Pada siklus I, alat peraga yang disediakan hanya tinggal digunakan langsung oleh setiap kelompok, walaupun demikian terlihat hanya baru beberapa siswa yang menggunakan alat tersebut dengan baik. Sedangkan pada siklus II alat peraga yang disediakan sebelumnya harus disediakan oleh siswa yang mereka miliki semakin terlihat dan terlatih. Maka dari itu terlihat perbedaan keterampilan proses yang dimilki setiap kelompok dari siklus I, dan II mengalami peningkatan.

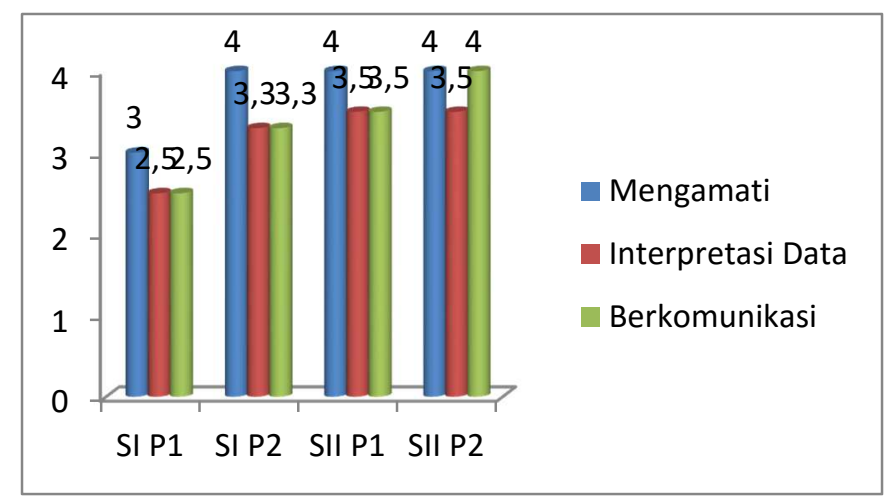

Gambar 2. Hasil Observasi keterampilan Proses Kelompok

\section{Hasil Observasi Keterampilan Proses Siswa pada Siklus I Pertemuan 1, Siklus I Pertemuan 2, Siklus II Pertemuan 1, dan Siklus II Pertemuan 2}

Hasil Observasi dalam keterampilan proses siswa mengalami peningkatan dari siklus I sampai ke siklus II . Keterampilan proses siswa yang mengalami peningkatan lebih cepat dari siklus satu ke siklus berikutnya adalah keterampilan proses berkomunikasi. Karena dari siklus I pertemuan 1 dan siklus I pertemuan 2, setiap siswa masih terlihat bingung bagaimana cara menyampaikan hasil dari kegiatan percobaannya, pada siklus II pertemuan 1 setiap siswa rata-rata jauh lebih pandai dan pintar dalam menyimpulkan atau menyampaikan hasil eksperimen yang mereka lakukan begitu pun pada siklus II pertemuan 2 lebih aktif dan kreatif lagi.

Rata-rata setiap keterampilan proses yang diperoleh dari semua siswa pada siklus I pertemuan 1 yaitu untuk keterampilan proses mengamati 2,8; keterampilan interpretasi data 2,6; dan keterampilan berkomunikasi 2,2. Pada 
siklus I pertemuan 2 rata-rata dari keterampilan proses mengamati 3,3; keterampilan interpretasi data 3,1; dan keterampilan berkomunikasi 2,3. Pada siklus II pertemuan 1 rata-rata dari keterampilan proses mengamati 3,4; keterampilan interpretasi data 3,3; dan keterampilan berkomunikasi 3,1 . Sedangkan Pada siklus II pertemuan 2 diperoleh hasil rata-rata dari keterampilan proses mengamati 3,7 ; keterampilan interpretasi data 3,7 ; dan keterampilan berkomunikasi 3,5. Pada siklus I masih terlihat banyak anak yang belum mencoba menggunakan alat peraga, mereka hanya melihat teman yang bekerja saja. Pada siklus II, sudah mulai terlihat antusias dan aktivitas yang dilakukan seluruh siswa semakin baik, karena pada siklus II alat peraga yang digunakan sebelumnya harus dibuat oleh siswa. Begitu pula pada siklus II pertemuan 2 siswa tampak semakin semangat dan trampil dalam menggunakan alat percobaan serta lebih memahami petunjuk dan langkah-langkah eksperimen. Dengan demikian, dapat dikatakan bahwa metode eksperimen dapat meningkatkan keterampilan proses siswa.

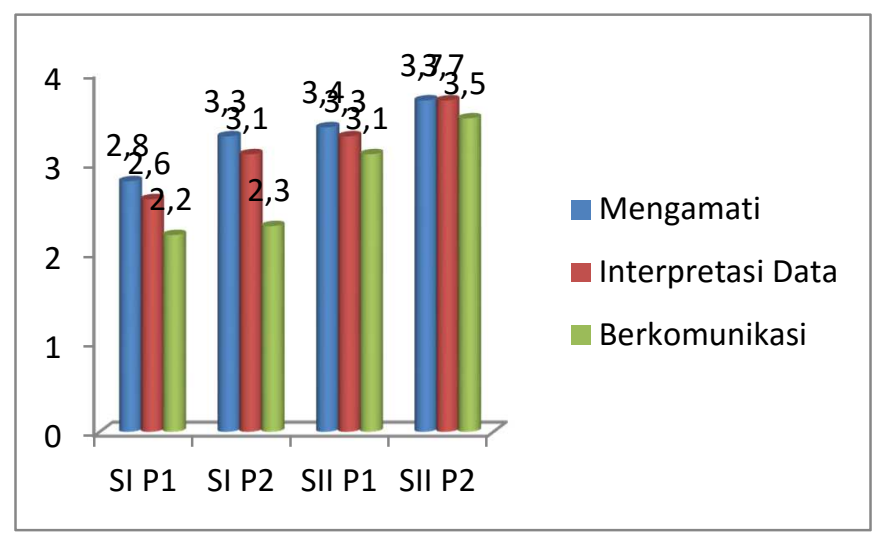

Gambar 3. Hasil Observasi Keterampilan Proses Siswa

D. Hasil Observasi Kegiatan Guru pada Siklus I Pertemuan 1, Siklus
Pertemuan 2, Siklus II Pertemuan 1, dan Siklus II Pertemuan 2

Hasil observasi yang dilakukan terhadap kegiatan guru selama pembelajaran berlangsung dalam menerapkan metode eksperimen setiap siklusnya mengalami peningkatan. Pada siklus I, masih banyak kekurangan yang signifikan yang dilakukan guru seperti kurangnya perhatian terhadap siswa yang sedang melakukan kegiatan percobaan apakah semuanya terlibat atau tidak. Selain itu guru tidak melakukan refleksi dan membuat rangkuman dengan melibatkan siswa.

Pada suklus II, guru kegiatan refleksi dan membuat rangkuman tidak terlihat sebagaimana terjadi pada siklus I. Kekurangan yang terjadi pada siklus I dan II, hampir semuanya tidak terjadi lagi pada siklus II/ P2 . Dengan kata lain, pada siklus II/ P2 kegiatan guru selama pembelajaran berlangsung dalam menerapkan metode eksperimen mengalami peningkatan yang cukup signifikan dibandingkan dengan kegiatan guru pada siklus I dan II.

Berikut ini adalah bukti adanya perubahan atau peningkatan kegiatan guru pada siklus II, yaitu :

- Dalam menguasai kelas guru sudah bisa mengatur siswa yang ribut dan gaduh dengan cara memberikan aturan dan sangsi ringan. Walaupun demikian masih saja ada sebagian kecil siswa yang ribut karena merasa terlalu senangnya melakukan kegiatan eksperimen/ percobaan.

- Penggunaan alokasi waktu sudah lebih baik dari siklus sebelumnya sehingga kegiatan refleksi dan membuat rangkuman yang melibatkan siswa dapat dilaksanakan.

E. Nilai Tes Hasil Belajar Siswa pada Siklus I Pertemuan 1, Siklus I 


\section{Pertemuan 2, Siklus II Pertemuan 1, dan Siklus II Pertemuan 2}

Nilai hasil belajar siswa yang dilakukan setelah pembelajaran selesai mengalami peningkatan setiap siklusnya. Sebagian besar siswa mengalami peningkatan dalam menjawab tes evaluasi hasil pembelajaran. Pada siklus II tidak terdapat seorang pun siswa yang nilainya turun. Hampir semua siswa mengalami peningkatan. Nilai ratarata yang diperoleh pada siklus II meningkat dibandingkan dengan raihan nilai rata-rata pada siklus I. Begitu pun tes hasil belajar pada siklus II/ P2 lebih meningkat lagi dibandingkan dengan siklus-siklus sebelumnya. Adapun nilai rata-rata hasil tes belajar siswa selama pembelajaran berlangsung dengan menerapkan metode eksperimen pada siklus II/ P2 yaitu 85,45, siklus II/ P1 diperoleh 80,68, sulkus I/ P2 yaitu 79 sedangkan nilai rata-rata hasil belajar siswa pada siklus I hanya diperoleh 67,72. Dengan demikian membuktikan bahwa pelaksanaan kegiatan percobaan/ eksperimen dalam pembelajaran IPA terutama pada materi ajar "Pengaruh kegiatan manusia terhadap keseimbangan lingkungan/ ekosistem" berdampak positif pada tingkat pemahaman konsep siswa terhadap materi pembelajaran tersebut.

Berdasarkan tabel di atas tentang pembahasan analisi hasil penelitian tentang nilai hasil belajar siswa pada pembelajaran IPA dapat disimpulkan terdapat adanya peningkatan hasil tes, yaitu pada siklus I pertemuan 1 dengan rata rata nilai 68,13 dengan ketuntasan belajar $54,17 \%$, Siklus I pertemuan 2 dengan rata-rata 72,29 dengan ketuntasan belajar $62,50 \%$, siklus II pertemuan 1 dengan rata-rata 80,21 dengan ketuntasan belajar $75 \%$ sedangkan rata-rata siklus II pertemuan 2 sebesar 85,83 dengan ketuntasan belajar 91,67\% . Dengan demikian peningkatan hasil belajar dapat dilihat pada grafik di 4.4 :

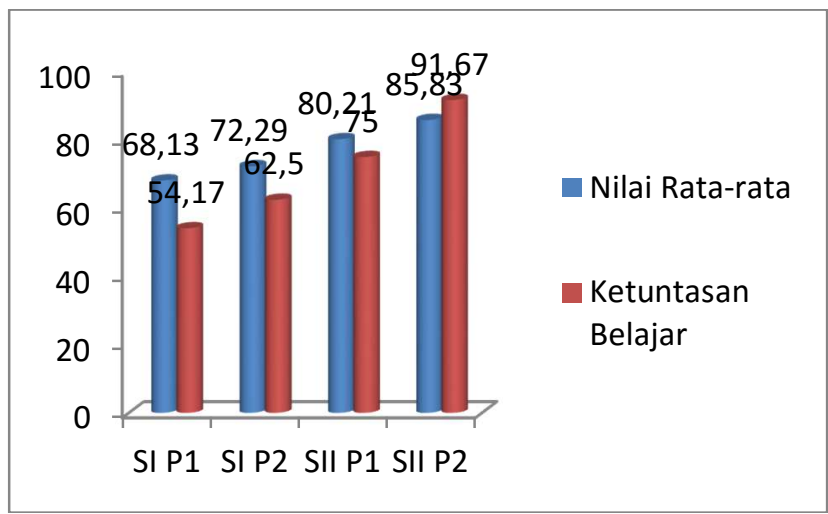

Grafik 4. Rata-rata Nilai Hasil Belajar

Siswa dan ketuntasan belajar

\section{F. Hasil Perolehan Angket}

Dari hasil angket yang dijawab siswa dalam setiap akhir pembelajaran adalah dapat meningkatkan minat dan kemampuan siswa dalam menguasai materi pelajaran serta melatih dan membiasakan siswa dalam menggunakan alat-alat peraga. Kesungguhan siswa terhadap kegiatan percobaan/ eksperimen sangat tinggi dan meningkat. Siswa yang sebelumnya tidak menyukai pelajaran IPA, dengan melaksanakan eksperimen membuat siswa menjadi siswa lebih menyukai pelajaran IPA. Siswa yang jarang sekali berbicara di depan kelas atau tidak terbiasa menyimpulkan materi, dengan melaksanakan eksperimen menjadi terlatih untuk melakukannya. Sebagian siswa yang asalnya masih bingung ketika menggunakan alat-alat peraga karena jarang sekali melakukan eksperimen, pada siklus II mereka mulai bisa menggunakan alat peraga sendiri dengan baik, lebih antusias, lebih teliti, dan lebih bisa mengamati apa yang mereka kerjakan, begitu pula pada siklus II pertemuan 2 lebih meningkat lagi. Hal ini membuat mereka tidak ragu-ragu, tidak sulit dan semakin mempermudah mereka dalam melakukan kemampuan keterampilan prosesnya. Pada siklus II sebagian besar siswa sudah bisa melakukan kegiatan eksperimen dengan waktu yang telah ditentukan dan lebih memuaskan lagi pada 
siklus II pertemuan 2 dari siklus-siklus sebelumnya.

Dari uraian di atas dapat dikatakan bahwa tingkat pemahaman konsep siswa kelas VI SD Negeri 4 Imbanagara Raya Kecamatan Ciamis Kabupaten Ciamis dalam pembelajaran Ilmu Pengetahuan Alam khususnya materi ajar "Pengaruh Kegiatan Manusia Terhadap Keseimbangan Ekosistem" menjadi lebih baik berkat diterapkannya metode eksperimen. Selain itu, kemampuan keterampilan proses siswa kelas VI SD Negeri 4 Imbanagara Raya Kecamatan Ciamis Kabupaten Ciamis menjadi lebih baik setelah pelaksanaan pembelajaran menggunakan metode eksperimen.

\section{KESIMPULAN DAN SARAN}

Berdasarkan hasil penelitian tentang Penggunaan Metode Eksperimen untuk Meningkatkan Pemahaman Konsep dan Keterampilan Proses Siswa Tentang Pengaruh Kegiatan Manusia Terhadap Keseimbangan Lingkungan dalam Pembelajaran IPA di Kelas VI SD Negeri 4 Imbanagara Raya Kecamatan Ciamis Kabupaten Ciamis, maka pada akhir penulisan Penelitian Tindakan Kelas ini dapat penulis simpulkan sebagai berikut.

1. Nilai rata-rata hasil belajar siswa yang diperoleh siswa pada siklus I pertemuan 1 sebesar 68,13; pada siklus I pertemuan 2 sebesar 72,29; pada siklus II pertemuan 1 sebesar 80,21 , dan pada siklus II pertemuan 2 sebesar 85,83. Ini berarti dari siklus I ke siklus II nilai hasil belajar siswa mengalami peningkatan . Dengan demikian dapat dikatakan bahwa penggunaan metode eksperimen dapat meningkatan pemahaman konsep pengaruh kegiatan manusia terhadap keseimbangan ekosistem pada siswa kelas VI SD Negeri 4 Imbanagara Raya Kecamatan Ciamis Kabupaten Ciamis.
2. Hasil observasi keterampilan proses siswa pada siklus I pertemuan 1 aspek yang paling menonjol dalam diri siswa adalah keterampilan mengamati. Rata-rata nilai dari seluruh siswa untuk ketiga aspek keterampilan proses mencapai 2,5 menunjukkan kriteria baik dengan persentase $63,2 \%$, dengan rincian nilai aspek keterampilan proses mengamati sebesar 2,8; aspek interpretasi data 2,6; dan aspek berkomunikasi 2,2. Pada siklus I pertemuan 2, rata-rata nilai aspek keterampilan proses yang paling menonjol adalah mengamati. Adapun rata-rata nilai siswa untuk ketiga aspek keterampilan proses pada siklus I pertemuan 2 adalah 2,9 yang menunjukkan kriteria baik sekalitau sebesar 73,4\%, dengan rata-rata setiap aspek keterampilan proses adalah aspek mengamati dengan nilai ratarata 3,3; aspek interpretasi data 3,1; dan aspek berkomunikasi 2,3. Begitu pula pada siklus II pertemuan 1 aspek keterampilan proses yang paling menonjol adalah mengamati. Adapun rata-rata nilai siswa untuk ketiga aspek keterampilan proses pada siklus II pertemuan 1 adalah 3,3 yang menunjukkan kriteria baik sekalitau sebesar $81,6 \%$, dengan rata-rata setiap aspek keterampilan proses adalah aspek mengamati dengan nilai ratarata 3,4; aspek interpretasi data 3,3; dan aspek berkomunikasi 3,1. Hal ini membuktikan bahwa kesungguhan siswa terhadap kegiatan eksperimen sangat membantu siswa dalam meningkatkan keterampilan proses. Begitu pula pada siklus II pertemuan 2 aspek keterampilan proses yang paling menonjol adalah mengamati. Adapun rata-rata nilai siswa untuk ketiga aspek keterampilan proses pada siklus II pertemuan 1 adalah 3,6 yang menunjukkan kriteria baik sekalitau 
sebesar 90,6\%, dengan rata-rata setiap aspek keterampilan proses adalah aspek mengamati dengan nilai ratarata 3,7; aspek interpretasi data 3,7; dan aspek berkomunikasi 3,5. Hal ini membuktikan bahwa kesungguhan siswa terhadap kegiatan eksperimen sangat membantu siswa dalam meningkatkan keterampilan proses.

3. Nilai dan hasil persentase kelompok dalam mengerjakan Jurnal eksperimen setiap siklusnya mengalami peningkatan. Pada siklus I pertemuan 1 rata-rata nilai yang didapat dari semua kelompok mencapai 82,5 atau sebesar $82,5 \%$, pada siklus I pertemuan 2 meningkat dengan nilai rata-rata 90 atau sebesar $90 \%$, pada siklus II pertemuan 1 lebih meningkat lagi dengan nilai rata-rata 92,5 atau sebesar 92,5\%. Hal ini membuktikan bahwa penggunaan metode eksperimen dapat meningkatkan kerjasama, diskusi dan kekompaka sehingga mendapatkan hasil/ nilai yang lebih baik. Sedangkan pada siklus II pertemuan 2 lebih meningkat lagi dengan nilai rata-rata 97,5 atau sebesar 97,5\%. Hal ini membuktikan bahwa penggunaan metode eksperimen dapat meningkatkan kerjasama, diskusi dan kekompaka sehingga mendapatkan hasil/ nilai yang lebih baik.

Hasil observasi keterampilan proses pada setiap kelompok memperlihatkan hasil yang cukup baik. Pada siklus I pertemuan 1 keterampilan proses yang lebih menonjol dan terlihat dari setiap kelompok adalah keterampilan proses mengamati (observasi), di mana para siswa menggunakan alat-alat indera yang dimilikinya. Rata-rata keterampilan proses yang diperoleh seluruh kelompok adalah 2,7 menunjukkan kriteria baik dan persentase $67,5 \%$. Dengan rata-rata setiap aspek keterampilan proses yang diperoleh dari jumlah seluruh kelompok adalah, aspek mengamati mendapatkan nilai ratarata 3; aspek interpretasi data 2,5 dan aspek berkomunikasi 2,5;. Pada siklus I pertemuan 2 setiap kelompok keterampilan proses berkomunikasinya mengalami peningkatan yang tinggi. Ratarata keterampilan proses yang diperoleh seluruh kelompok adalah 3,5 menunjukan kriteria baik sekali dan persentase $87,5 \%$. Dengan rata-rata setiap aspek keterampilan proses yang diperoleh dari jumlah seluruh kelompok adalah, aspek mengamati mendapatkan nilai rata-rata 4; aspek interpretasi data 3,3; dan aspek berkomunikasi 3,3. Sedangkan Pada siklus II pertemuan 1 setiap kelompok, keterampilan proses berkomunikasinya mengalami peningkatan yang tinggi. Ratarata keterampilan proses yang diperoleh seluruh kelompok adalah 3,7 menunjukan kriteria baik sekali dan persentase $87,6 \%$. Dengan rata-rata setiap aspek keterampilan proses yang diperoleh dari jumlah seluruh kelompok adalah, aspek mengamati mendapatkan nilai rata-rata 4; aspek interpretasi data 3,5; dan aspek berkomunikasi 3,5. Sedangkan Pada siklus II pertemuan 2 setiap kelompok, keterampilan proses berkomunikasinya mengalami peningkatan yang tinggi. Ratarata keterampilan proses yang diperoleh seluruh kelompok adalah 3,8 menunjukan kriteria baik sekali dan persentase 92,5\%. Dengan rata-rata setiap aspek keterampilan proses yang diperoleh dari jumlah seluruh kelompok adalah, aspek mengamati mendapatkan nilai rata-rata 4 ; aspek interpretasi data 3,5; dan aspek berkomunikasi 4. Hal ini membuktikan, bahwa dengan adanya penggunaan metode eksperimen membuat setiap siswa bisa menampilkan dan melatih keterampilan prosesnya yang belum terlihat dan tergali, bahkan melatih siswa untuk berbicara di depan kelas.

Berdasarkan simpulan di atas, penulis sampaikan beberapa saran sebagai berikut. 
1. Dengan dipererolehnya gambaran tentang kemampuan keterampilan proses siswa yang terjadi melalui nilai dan persentase, maka guru harus lebih dapat mengembangkan pembelajaran dengan keterampilan proses melalui metode eksperimen dengan menggunakan alat peraga yang sederhana yang dapat menunjang materi yang akan diajarkan.

2. Bagi peneliti lain, dengan melihat kekurangan yang terjadi dalam penelitian ini, diharapkan sebelum melakukan penelitian harus siap dan tegas kepada siswa yang memungkinkan mengganggu dalam kegiatan pembelajaran.

\section{Daftar Pustaka}

[1] Ahmad, H. D, dkk.. (1995). Metodik Khusus Pengajaran Ilmu Pengetahuan Alam Di Sekolah Dasar. Jakarta: Depdikbud.

[2] --------------, (1995). Petunjuk Pelaksanaan Penilaiaan di Sekolah dasar.

Jakarta: Depdikbud.

[3] Ali, M. (1984). Guru dalam Proses

Belajar Mengajar. Bandung: Penerbit Sinar Baru.

[4] Arikunto, S. (2001). Dasar-dasar Evaluasi pendidikan. Jakarta: Bumi Aksara.

[5] Badan Standar Nasional Pendidikan (BNSP). (2006). Kurikulum Tingkat Nasional Satuan Pendidikan, Mata Pelajaran IPA SD. Jakarta: Depdiknas.

[6] Dahar, R. W. (1996). Teori-teori Belajar. Jakarta:Erlangga.

[7] Departemen Pendidikan Nasional, (2005). Kamus Besar Bahasa Indonesia. Jakarta: Balai Pustaka.

[8] Ibayati, Y.,dkk.(2008).Ilmu Pengetahuan Alam untuk SD dan MI. Jakarta: Depdiknas.
[9] Iskandar, M. S. (1996). Pendidikan Ilmu Pengetahuan Alam. Depdikbud. Dirjendikti.

[10]Lisnawati, L. (2010).Penggunaan Metode Eksperimen Dalam Pembelajaran IPA Untuk Meningkatkan Pemahaman Konsep Siswa Pada Topik Energi Bunyi.Tidak diterbitkan.

[11]Nurkancana, W dan Sumartana. (1983). Evaluasi Pendidikan. Surabaya. Usaha Nasional.

[12]Panut, H, dkk. (2004). Dunia Sains. Bandung: Yudistira.

[13]Rustaman, A \& Nuryani. (1996). Penilaian Keterampilan Porses IPA di Sekolah Dasar, Depdikbud.

[14]Semiawan, C, dkk. (1985). Perdekatan Keterampilan Proses. Jakarta: Penerbit PT Gramedia.

[15]Suhartanti, D. (2008). Ilmu Pengetahuan Alam untuk SD dan MI Kelas VI. Jakarta: Depdiknas

[16]Winataputra, U,S., dkk. (1992). Strategi Belajar Mengajar IPA. Jakarta: Depdikbud.

[17]Wiriaatma Ija, R, (2007). Metode Penelitian Tindakan Kelas. Bandung: Remaja Rosdakarya.

[18]Kasbolah, K.E.S. (1998). Penilitian Tindakan Kelas. Malang: Depdikbud Dirjen Dikti. 